\title{
LEXICAL ERROR IN WRITING ENGLISH WORDS MADE BY STUDENTS OF THE JUNIOR HIGH SCHOOL
}

\author{
Bahrun Amin \\ English Education Department, Faculty of Teacher Training and Education \\ Muhammadiyah University of Makassar \\ bahrunamin@unismuh.ac.id
}

\begin{abstract}
The objectives of the research are to find out: The lexical error in writing English noun made by the eighth grade students of SMP Unismuh Makassar. The lexical error in writing English adjective made by the eighth grade students of SMP Unismuh Makassar. What lexical error in writing English verbare made by the eighth grade students of SMP Unismuh Makassar. The result of this research is give information caused of lexical error of the student's ability in writing English noun and adjective specially. For teacher: the result of this research can be a knowledge and references to all teacher why their students has low ability in writing vocabulary, and also find out solution so that can create students whose more quality. For students: make students realize about their mistake in learning vocabulary and they can repair their mistake by changes their way in study vocabulary. For researcher: it can be knowledge and references for researcher about the cause of lexical error in writing English words, it also becomes a description about some problem that faces in the school especially to students. And it can be make research have more knowledge how to be a good teacher in the next future.
\end{abstract}

Keyword: Lexical, writing, Junior high school, vocabulary, error

\section{INTRODUCTION}

Communication is a means of people for interaction with each other. By communication, people can exchange information or ideas between individuals. There are two kinds of communication that can be used; they are spoken communication and written communication. In spoken communication, the most important thing is the hearer can understand what the speaker means. Besides, between the speakers are also allowed to make back-and-forth process of negotiations meanings. According to Abisamra (2003), communication is the basis of life, it is at the heart of all human interactions. On the other hand, writing is a complex task. It can be said as the most difficult of the language abilities to acquire (Allen and Corder: 1974). Because in written texts, the sense of the dialogue between the writer and the reader is impossible to make negotiation of meanings as in spoken conversation. The sentence is written and it is read. 
Therefore, if the writer does not master the target language well, the problem of misunderstandings will be often found in their written text.

For English learners, they are expected to be able to use the English language not only in spoken, but also in written communication. Since writing is one of the language skills that should be mastered. Written language can be analyzed by identifying the lexical items that they apply in the sentences. It means that lexis is one of the important elements that needs to produce and also understand the text well. There are two aspects that should be noticed by the learners to build a good sentence; they are grammatical aspects and lexical aspects. English grammar is applied to provide a general pattern of rule in combining words to phrases, and phrases to sentences. A good grammar will influence a good written communication, because the written text without applying the rules will invite misinterpretations for readers. They will not be able to read accurately. A good grammar in written text will ease the reader to understand its content. Hence, miscommunication sometimes happens among people because of the grammatical error. The second urgent aspect needed in building sentences is lexical aspect. It relates to the vocabulary or words in the dictionary. In English, nouns, verbs, adjectives, and adverbs make up the largest part of the vocabulary (Fromkin 1997).

In written communication, the learners have to take and use the words correctly in order that the messages that want to be delivered are understandable. Every word is the center of a constellation which all parts support each other (Mackey, 1984). So that lexical aspect cannot be ignored in producing sentences. However, most English learners do not give a significant attention to the lexical aspect. They still often make errors in their sentences. They suppose lexical is not a complicated problem, since it can be looked easily in dictionary. Lexis is the basic element which is very important to communicate, especially in written communication. Because an idea is impossible can be transferred without the lexis. Furthermore, Ramli proposed in his paper (2002), that lexis is considered as a very crucial thing to be mastered in human's life because by mastering lexis, we can understand a text or communicate with others. 
By lexis, we will also be able to do anything such as express our feeling, share ideas, or deliver messages to others. In other words, there is a positive correlation between one's knowledge and lexical items comprehension. More lexical items comprehended by someone, automatically he has a wide knowledge because he will be easier to convey and receive information. Lexical aspect is a very crucial thing to be learnt and can be considered as a complicated problem, because many English learners often make lexical errors when they produce English sentences. It is proved by the result of a research donebyNapitupulu (2005). She investigated the lexical errors in English compositions of 25 English study program students from language and art faculty of HKBP Nommensen Medan University. The study finds out that there are 387 lexical errors made and the most dominant type of lexical errors is in the category of distortion for 220 items. In addition, the dominant cause of error is intralingua error, where the students find the difficulty in the target language.

Based on the view mentioned above, the researcher concludes that lexical item is the major element that must be used in written or spoken communication. Then, lexical aspect becomes very important to be learnt, especially for English learners, because the learners will find difficulty to produce coherent and meaningful texts if their mastery of English lexis is still restricted and their learning of the use of lexis is imperfect. Therefore, there are still many lexical errors in their English sentences. This is why the researcher interested in conducting this study.

\section{THE CONCEPTUAL OF ERROR}

According to Paul Brians on his book "Common Error in English Usage" said that the errors others make in English differ according to the characteristics of their first languages. Speakers of other languages tend to make some specific errors that are uncommon among native speakers, so you may also want to consult sites dealing specifically with English as a second language.

Hendrickson in NurChaimah thesis (2007) "lexical error of English written by the students of Al-Hikmah Al-Fithimiyyah school " said that the word 'error' itself is derived from Latin word errare its meaning is 'to wander, to stray, 
roam. Actually the meaning of error depends on particular purpose. Because every words has different meaning if it placed in different places even it can be change the meaning of the words itself.

Croft (1980) error and mistake are two terms which similar, although in the context linguistic those are different. Mistake is a random performance slip because by fatigue, excitement etc., and error is systematic deviation made by the learners who have not yet master the rule of the target language. It means errors not only caused by the students mastering in their subject but also caused by students' condition in face their subject so that they made errors.

According to Shridar (1980) states that by identifying the learner's error educators be able to: (a) determine the sequences of presentation of target items in textbook (b). Emphasis, explain and practice a various items about language target (c) plan and arrange remedial lesson and exercise. Shidar has systematical technique in identified learning errors where the first step she determine the presentation of language target, then explain more the students' error and the last give them remedial or chance to repair their error.

To distinguish of between an error and mistake, Ellis (2003) suggest two ways. The first one is to check the consistency of learner's performances, sometimes use the correct form and sometimes the wrong one, it is a mistake. However they always use it in incorrectly, it is then an error. The second way is to ask learner to try to correct his own deviant utterances. Where they unable to, the deviations are error; where he is successful, they are mistakes. In this statement Ellis give ways how to identify between error and mistake where mistake is an activity that sometimes students do and they can make it correct again. And errors is an activity that students really doesn't know and it always happen and the students could not repair it expect if they learn their subject deeply. As Miller in Corder (1967) states that errors of performance refer to mistakes and the systematic errors refer to error of the learner from which we are able to reconstruct his knowledge of the language, as it is called transitional competence. Transitional competences mean a period where the students find out ways to repair their errors and more understand about their errors. 
Conceptual of error above we can conclude that error in learning process important distribution to understand the language learning process. When investigating the learner's errors, it is essential to know the kinds of error, and differentiate between systematic and non-systematic error. We often find in normal adult speech the errors of one sort or another. Those errors are usually caused by memory lapses, physical states, such as tiredness, physical conditions, and a strong emotion. The previous causes of errors are not related to the knowledge of language, but it can be said as the errors of performance. The learners will immediately be aware and correct those errors.

\section{Kinds of Error}

There are two kinds of errors namely interlingua error and intralingua errors.

a. Interlingua Errors

Richard (1974) states that Interlingua errors are errors caused by interferences of the learner's mother tongue. Errors of this nature are frequent, regardless of the learner's language background. Therefore, Interlingua errors are caused by interferences of native language to the target language they learn. Before someone masters the concept of target language they will always use their native language. This kind of error is called Interlingua error.

b. Intralingua errors

The other kind of error is intralingua error. According to James (1998) the less of learner's know about the target language, the more be is forced in draw upon any other prior knowledge. It is because the learners do not know much about the target language.

According to Richard (1970) intralingua error produce by the learners which not reflect to the structure of the mother tongue, but generalization based on partial exposure to the target language. In a analysis of English error produce by the speakers of a multitude of unrelated language representing several language families. Richard notes subcategories of error types which seem to the common to 
speaker of diverse language as they develop hypothesis that correspond neither to the mother tongue nor target language.

Channell (1981) cited four types of errors, namely, wrong collocation, native language induced errors, overuse of general terms, and insufficient generalization. She found that lexical errors resulted from the lack of emphasis on vocabulary in most syllabuses.

\section{Lexical Error}

Ellis, R 1994 states that Lexical errors are the most frequently occurring category of errors in written English. They significantly affect the quality of academic writing and native speakers consider them the most irritating. Ellis states means that lexical errors is has categories specially in writing, if the percentage of error are low it means quality of academic writing are good and if the percentage of students writing are high it means academic writing of students is low.

Carter (1998) suggests that 'mistakes in lexical selection may be less generously tolerated outside classrooms than mistakes in syntax'. This is probably because lexical selection consists mainly of content words, which convey the intended message. When lexical word selection, the reader can lead directly to misunderstanding of the message, or at least to an increase in the burden of interpreting the text. Since lexical errors are potentially so disruptive. Carter means that miss election in choice word for sentences it will be one of cause of lexical error so that it will disturb students understanding in learning the target language or the message of a text or sentences.

Rene Dirven “Cognitive Explorations of Language and Linguistics (2004) "define that lexical is a systematic analyze about the aim of conversation or saying. In Rene's book he writes that in learning about lexical need a systematic analyze in speaking, where here is there are rules how to start the conversation and how to convey our goals.

S. Nathesan (2000) lexicon is called lexemes or word forms. Lexemes are not atomic elements but contain both phonological and morphological 
components. When describing the lexicon a reductionist approach is used, trying to remain general while using a minimal description.

By some previous above we can conclude that lexical has strong relation with word and vocabulary, directly this lexical contain vocabulary as it part. Because of lexical talk about vocabulary start from basic meaning of vocabulary until analyze about it. Where in lexical divide part that analyze about vocabulary likes lexicographer that has obligation makes words into dictionary where it's no easy to make it. Beside that in lexical there is lexicology that arrange form of words, how to all vocabulary has a form in order the learners easy to learn it know all aspect of vocabulary by lexical, and also analyze the meaning of words or sentences.

\section{RESEARCH METHOD}

This research used descriptive research method to describe the factors of Lexical errors in Writing English Words is made by the Eight Grade in SMP Unismuh Makassar. The sample this research applied of A class students of the eight grade year in SMP Unismuh Makassar. The instrument of this research was asked to students written descriptive text which according to the syllabus to known some information about lexical error of students in writing English words. By using this instrument the researcher was analyzed detail information about lexical error in writing English words were made by the eighth grade students of SMP Unismuh Makassar. In collecting data, the researcher submitted all descriptive text from students. And then the researcher identified lexical error of the students in writing English words. Before asked to students to made descriptive text, researcher gave explanation about descriptive text detail, so that students could know what did the descriptive text exactly. The data of the lexical error in writing English words made by the eighth grade students of Unismuh Makassar obtained through the task that given to students are the researcher identified and made list for every errors made by the students in writing descriptive paragraph, and the researcher classified every lexical error in writing descriptive text into noun and adjective, then classified based on the lexical errors types followed by explanation of each types of error. 


\section{FINDING AND DISCUSSION}

It was identified there were 198 errors and it was classified the errors all errors classified into words classes to know their each word classes includes noun, adjective and verb. Then their each error classified based on lexical classification. After that, the researcher percentages each errors in word classes then of each word classes percentage the researcher would combined with all totals percentage of lexical classification. Table below showed us all errors which found in the writing result of SMP Unismuh Makassar.

\section{Lexical Errors in English Noun}

In this research, the researcher found that lexical errors in English noun were the biggest errors by 120 errors or $60,6 \%$. Table below show us the total percentage of lexical errors in English noun were made by the eighth grade students of SMP Unismuh Makassar.

\begin{tabular}{|c|c|c|}
\hline Kinds of Errors & Errors in Noun & Totals percentages \\
\hline $\begin{array}{l}\text { Formal Miss election } \\
\begin{array}{l}\text { a. Suffix } \\
\text { b. Vowel based type }\end{array}\end{array}$ & $\begin{array}{c}2 \\
29\end{array}$ & \\
\hline $\begin{array}{l}\text { Misformation } \\
\begin{array}{l}\text { a. Borrowing } \\
\text { b. Coinage } \\
\text { c. Calque }\end{array}\end{array}$ & $\begin{array}{l}5 \\
2\end{array}$ & \\
\hline $\begin{array}{l}\text { Distortion } \\
\begin{array}{l}\text { a. Omission } \\
\text { b. Over inclusion } \\
\text { c. Miss election }\end{array}\end{array}$ & $\begin{array}{l}22 \\
11 \\
49\end{array}$ & \\
\hline $\begin{array}{l}\text { Totals errors of English } \\
\text { noun }\end{array}$ & 120 & \\
\hline $\begin{array}{l}\text { Totals errors of lexical } \\
\text { errors }\end{array}$ & 198 & $60,6 \%$ \\
\hline
\end{tabular}




\section{Lexical Errors in Adjecctive}

The researcher found that lexical errors in English adjective were the biggest errors by 52 errors or $26,26 \%$. Table below show us the total percentage of lexical errors in English adjective were made by the eighth grade students of SMP Unismuh Makassar.

\begin{tabular}{|c|c|c|}
\hline Kinds of Errors & Errors in Adjective & Totals percentages \\
\hline Formal Miss election & 2 & \\
d. Suffix & 8 & \\
Misformation & \multicolumn{2}{|c|}{} \\
d. Borrowing & 1 & \\
e. Coinage & & \\
f. Calque & 18 & \\
\hline $\begin{array}{c}\text { Distortion } \\
\text { d. Omission }\end{array}$ & 9 & \\
e. Over inclusion & 14 & \\
f. Miss election & $\mathbf{5 2}$ & \\
\hline $\begin{array}{l}\text { Totals errors of English } \\
\text { Adjective }\end{array}$ & $\mathbf{1 9 8}$ & $\mathbf{2 6 , 2 6 \%}$ \\
\hline $\begin{array}{l}\text { Totals errors of lexical } \\
\text { errors }\end{array}$ & & \\
\hline
\end{tabular}

\section{Lexical Errors in english Verb}

The researcher found that lexical errors in English adjective were the biggest errors by 52 errors or $26,26 \%$. Table below show us the total percentage of lexical errors in English adjective were made by the eighth grade students of SMP Unismuh Makassar.

\begin{tabular}{|l|c|c|}
\hline Kinds of Errors & Errors in Adjective & Totals percentages \\
\hline Formal Miss election & 2 & \\
e. Suffix & 2 & \\
f. Vowel based type & & \\
\hline Misformation & & \\
\hline
\end{tabular}




\begin{tabular}{|c|c|c|}
\hline $\begin{array}{c}\text { g. Borrowing } \\
\text { h. Coinage }\end{array}$ & \\
i. Calque & & \\
\hline $\begin{array}{c}\text { Distortion } \\
\text { g. Omission }\end{array}$ & \\
h. Over inclusion & 2 & \\
i. Miss election & 5 & \\
\hline $\begin{array}{l}\text { Totals errors of English } \\
\text { Adjective }\end{array}$ & $\mathbf{2 6}$ & \\
\hline $\begin{array}{l}\text { Totals errors of lexical } \\
\text { errors }\end{array}$ & $\mathbf{1 9 8}$ & $\mathbf{1 3 , 1 3 \%}$ \\
\hline
\end{tabular}

After the researcher identified all writing result of SMP Unismuh Makassar, researcher found there were 198 errors. Then researcher classified each errors into words classes includes noun, adjectives and verb and in this section researcher found there were 120 errors in noun, 52 errors in adjective and 26 errors in verb. And the dominant errors between those words classes were error in noun.

Theory for identifying the lexical errors is based on Legenhausen theory, which are categorized into three types, they are, formal miss election, misformation, and distortion. Then, the errors in formal miss election are classified into four types: error in suffix, prefix, vowel-based, type. Then errors in misformation are classified into three types: coinage, borrowing, and calque. The last is distortion which can be classified into omission,overinclusion, miss election, and misordering. After the detail explanation above, the researcher would cobine totals errors of words classes into one table as conclusion of this findings. The researcher can conclude the totals error of words classes in lexical classification in the table, as shown below: 


\begin{tabular}{|c|c|c|c|c|c|}
\hline Kinds of Error & \multicolumn{4}{|c|}{ Occurances } & \multirow{2}{*}{ Percentages } \\
\hline $\begin{array}{c}\text { Formal Miss } \\
\text { election }\end{array}$ & Noun & Adjective & Verb & $\begin{array}{c}\text { Total of } \\
\text { classification }\end{array}$ & \\
\hline a. Error in suffix & 2 & 2 & 2 & 6 & \\
\hline $\begin{array}{l}\text { b. Error in vowel } \\
\text { based type }\end{array}$ & 29 & 8 & 2 & 39 & $22,73 \%$ \\
\hline \multicolumn{6}{|l|}{ Misformation } \\
\hline a. Borrowing & 5 & & & 5 & \\
\hline b. Coinage & 2 & & & 2 & $4,03 \%$ \\
\hline c. Calque & & 1 & & 1 & \\
\hline \multicolumn{6}{|l|}{ Distortion } \\
\hline a. Ommision & 22 & 18 & 15 & 55 & \\
\hline b. Over inclusion & 11 & 9 & 2 & 22 & $73,25 \%$ \\
\hline c. Miss election & 49 & 14 & 5 & 68 & \\
\hline $\begin{array}{l}\text { TOTAL of words } \\
\text { classes }\end{array}$ & 120 & 52 & 26 & 198 & \\
\hline Percentages & $60,6 \%$ & $26,26 \%$ & $13,13 \%$ & 100 & \\
\hline
\end{tabular}

From the table above, in noun category there were 120 errors or $60,6 \%$ and in adjective category there were 52 errors or $26,26 \%$, and in verb category there were 26 errors or $13,13 \%$. The total of those words classes were 198 errors and the total of percentage were $100 \%$. Then, the researcher found the totals of lexical errors. The first category were formal miss election category includes suffix there are 6 errors and in vowel based type there are 39 errors the total of this category is $22,72 \%$. Then, misformation category in borrowing there were 5 errors, in coinage there were 2 errors and calque there were 1 error the total of errors were 4,03\% Then, the third category were Distortion, in omission there are 53 errors, in over inclusion there were 21 errors, and miss election there were 71 errors the total were $73,25 \%$. After researcher accounted all the lexical errors classification found that there were $100 \%$ errors. As table above, concluded that distortion category is the dominant kinds of error made by the eighth grade students at SMP Unismuh Makassar. 


\section{DISCUSSION}

After analyzing the data and classifying them based on the lexical errors categories, the researcher intends to discuss the findings that have been investigated in this section to answer the research questions.

\section{Lexical errors in noun}

Noun is refers to things, person, or place. For example, lake, sea, girl, friend, library, Indonesia, india, Susilo BambangYudhoyono, school, students, teacher, table, ect

$>$ Lake and sea are noun because name of river and it mostly same with places.

$>$ Girl and friend are noun because those are person.

$>$ Indonesia and India are noun because those are name of places (country)

From the students writing result, the researcher found that noun were the dominant errors it showed on the table above where noun has 20 errors, errors in adjective there were 52 errors and the last is verb there were 26 errors.

\section{a. Errors of noun in formal Miss election}

As the appendix showed that in formal miss election error in lexical items that is characterized by applying incorrect word because the meaning looks and sound resemble. And this category includes errors of noun in suffix and errors of noun in vowel based type, in this classified researched found 6 errors of noun in suffix and 39 errors of noun in vowel based type were made by the eighth grade students of SMP Unismuh Makassar.

The first were errors of noun in suffix researcher found that students wrote words students cannot differentiate when a words has function as noun and when the words has function as verb. in this study only investigates the errors in derivational suffix from the students' writing, since derivational suffix can change the identity of lexical item or the meaning of word. From investigating the errors in suffix the researcher found 6 errors; the examples of suffix error are as the following sentences:

- $\quad *$ The store is very very very good and attract. 
The store is very good and attractive.

- *She is usually sensation at self

She is usually sensational by herself.

Many of the errors made were as a result of the student's lack of understanding in differentiating the word class. For instance, to reveal the adjective form, the students did not add the suffix to the noun. As in the word sensation, attract, it should be sensational because the suffix "tional", attract it should be attractive because the suffix " ive".

The second is errors of noun in vowel based type, errors in noun also appeared in vowel based type. Wowel-based type is a kind of error in spelling of written work here, the writer commits error in the vowel form of a word. After analyzing the data, the researcher can found 39 errors in vowel-based type such as;

*She has tall posture ting it should be She has body posture $\underline{\text { slim }}$ and tall.

*She wears ting in her left hand. It should be She wears ring in her left hand.

*She wear a brecelet. It should be She wears a bracelet.

*She wear balt, but variable. It should be She wears belt, and it's various.

The underlined words are incorrect because the writer did not know the right vowel after the other vowel as in sentences 1, 2, above. For example: the word ting in the first sentences and the second sentences should be slim and ring. Then, for the sentence 3, 4 and 5 the writer chose the consonant $\underline{e}$ for brecelet and a for balt, meeting as a result of analogy with such item as getting. Some of the errors in vowel-based type made because the students' lack of understanding of the English spelling. Most of errors error above showed that the student committed lexical error by writing error spelling of a vowel. 


\section{b. Error of Noun in Misformation}

The first borrowing is the insertion of a first language word without any attempt at adapting it to the target language. In this research are found 7 errors in borrowing, and the examples of this error are:

*She hobby are eat, pray, wathing tv, reading komik.

Her hobbies are eating, praying, watching TV, reading comic

*She is student of universitas in South Korea.

She is student in one of university in South Korea.

*She kawan solidarity.

She is loyal friend.

*She have desira the dokter animals spesialis.

She has desire to be a specialist doctor of animals.

As can be seen, there are insertion of the first language in the above sentences. Here, the students did not know the English lexis to represent what they mean. This error occurred since the students did not have adequate lexical knowledge of English. They directly adopt those words from their mother tongue without any effort to change it to the English. For the correct sentences, can be observed in sentence above.

The second is coinage Coinage errors are characterized by giving rise to adapted first language word, so that they sound and look like English. This type of error has only 2occurrences in the students' compositions, as the following sentences:

*My mother is have adjectiv kain and lovely children and sesame.

My mother has character kind (adjective) and lovely children and another peoples.

*I clear pink dacter. (daster)

I wear pink long dress.

Those two sentences appeared two incorrect words they are, sesame and dacter. In the first sentence, "sesame" is Indonesian language but the students didn't tried to change it word, which has meaning as the word all people. Then, in the second sentence the word "dacter" it word students means daster and it is Indonesian language, students should be tried hange the word become long dress. 
The third is calque it refers to designing a second language word resulting from literal translation. From the data of this study are found 1 error in calque:

*She sometimes hot head.

She is sometimes stubborn.

In the sentences above, the researcher finds the type of calque errors. The students considered used word "hot head" to describe her friend's characters, students write the word above means "keras kepala" incorrect if that word written literally because it's not improperly with dictionary so, it should be "stubborn".

\section{c. Lexical of noun in distortion}

The lexical error in distortion is caused by incomplete application of rules. There are four categories of distortion, they are, omission, over inclusion, miss election and misordering. From the data available the researcher states that distortion is the most dominant error occur in the students' English writing with 145 errors found.

The first is errors of adjective in omission, omission is the omission is characterized by giving rise to some an existent word. Errors of omission occur when the students omit the item that should exist in the correct lexis. Generally, the students omit the vowel item or the consonant item. This is because the students lack of mastering English lexical items, especially in writing the syllables.

*Her eye are around

Her eyes are around

*She was gotten appretation of SCTV oward.

She was gotten appreciation of SCTV award.

*I have many friend.

I have many friends.

Example above is one of students" errors in noun, in "eye" it should be "eyes" because it were plural. Next is "appretation" it should be "appreciation" students written were lack of "c" to make the word were 
correct. For the last example "friend" it should be "friends" because before it word is plural.

The second is error of noun in over inclusion, Over inclusion is the opposite of omission here the students add the inexistent item that should not be appeared in the correct word as the following examples showed:

*And nurul she is a student.

And she is a student.

*Color it is my bag pink, white.

My bag colors are pink and white.

The word nurul and she used in sentence 1 is redundant, because we already know that she basically are similar with name of a girl, to differentiate is just on their position. And also some over inclusion sentences above students used word "Color it is my bag" the word "it is" refers to bag so, no need to include "it is" but we can write my bag directly. The students committed errors caused by incomplete application of English rules. They add the items that should not be existent in well-formed word.

The third is miss election, miss election is Miss Election occurs when the students cannot choose the appropriate word when constructing a wellformed sentence. Miss election error in this research has the highest frequency from the other types of errors with 71 errors. Below are some examples of miss election from the students' composition to illustrate these errors:

*I like with eyes because...

I like her eyes because...

*Cat, rabbit, hours.

Cat, Rabbit, horse.

* She hobby are eat, pray, wathing TV, reading komik.

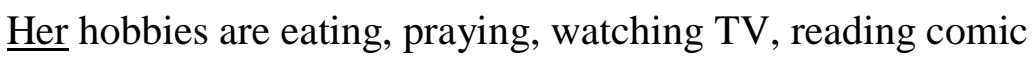

As we can see, there are many miss choice of errors in the students' writing. The above error sentences are evidence that the students lack of 
English lexical items. The words with, hours in sentence 1, 2 were inappropriate The students wrote $i$ like with eyes but that words is not what the student wants to The correct word choice for sentences 1 is her, horse for sentences 2. Beside miss election word on their sentence, students also still have low mastery of to be (am, is, and are) and when the noun is more than one. For example "she are beautiful" are is incorrect when the subject is plural so, it should be is.

\section{Lexical error in adjective}

Adjective is words describes about characters of a things, noun or pronoun big, fat, black, expensive beautiful, handsome ect. Here are some specifics characteristics of adjective: first, Adjectives are words which describe only nouns. They tell what kind? Or how many. The second, the noun markers a, an, and the are always adjectives. The third, Adjectives pile up in front of nouns. For example: the big, red, flashy car. The fifth, All underlined words are adjectives describing the noun car. Adjectives may also follow a linking verb and describe the subject of a sentence. For example: The car is big, red, and flashy. The word endings -able, -ful, - ible, - ical, ious, -ive, -y usually form adjectives. Some clue above could be direction for us to know or identified adjective. Some sentences below are example of adjective in sentence:

Sally is a nice person and you can speak freely with her.

We saw beautiful valleys.

My mother is a humble person.

Their attitude is $\underline{\text { bad. }}$.

Donnas' dog is very big, fat and black color.

From the students writing result, the researcher found that noun were the dominant errors it showed on the table above adjective there were 52 errors.

\section{a. Errors of adjective in formal miss election}

Errors of adjective in formal miss election were divided into two types. The first is errors of adjective in suffix, for example:

$*$ She forever tich for kain. 
She forever teaches for kindness.

Many of the errors made were as a result of the student's lack of understanding in differentiating the word class. For instance, to reveal the adjective form, the students did not add the suffix to the noun. As in the word "kind" it should be kindness because the suffix "ness", all suffix are used to change adjective form into noun form eat and pray gives suffix "ing" should be eating and praying to change verb form into noun.

The second is errors of adjective in vowel based types, as we know that vowel-based type is a kind of error in spelling of written work. Here, the writer commits error in the vowel form of a word. After analyzing the data, the researcher found errors in vowel-based type such as;

*His hair is black broand.

His hair is black broand.

*She is short, plat nose, talkive, sensation.

She is short, flat nose, talkative, sensational.

*She wears ting in her left hand.

She wears ring in her left hand

The underlined words are incorrect because the writer did not know the right vowel after the other vowel as in sentences above the word "broand" in the first example it should be "brown". The second example "plat nose" it should be "flat nose". And the last example the word "ting" it should be "ring". Some of the errors in vowel-based type made because the students' lack of understanding of the English spelling. And also the students had not really mastered the English spelling, therefore they used inappropriate vowel in their sentences. Most of errors error above showed that the student committed lexical error by writing error spelling of a vowel.

\section{b. Lexical errors of adjective in Misformation,}

Misformation has three types. The first is borrowing, but in this type were not errors appeared. The second is coinage, and in this type there were not errors appeared too. 
And the last is calque, Calque refers to designing a second language word resulting from literal translation. From the data of this study are found 1 error in calque:

- $*$ She sometimes hot head.

She is sometimes stubborn.

In the sentences above, the researcher finds the type of calque errors. The students considered used word "hot head" to describe her friend's characters, students write the word above means "keras kepala" incorrect if that word written literally because it's not improperly with dictionary so, it should be "stubborn".

\section{c. Errors of adjective in Distortion}

The lexical error in distortion is caused by incomplete application of rules. There are four categories of distortion, the first is omission characterized by giving rise to some an existent word. For example:

*Aura is beatiful and sweet.

Aura is beautiful and sweet.

*The characteristic of cica are talkative and arogan.

Cica's characteristics are talkative and arrogant.

*She have hair short, curl.

She has short and curly hair.

The words occur in the other sentences "beatiful, arogant, curl" students omitted a consonant item that must be appeared in correct lexis. In the word "beatiful" it should be "beautiful", and for the second example "arogan" it should be "arrogant" and the last example "curl" it should be "curly". Students omitted a consonant item that must be appeared in correct lexis.

The second is over inclusion, Over inclusion is the opposite of omission here the students add the inexistent item that should not be appeared in the correct word as the following examples showed:

*She is very very kind. 
She is very kind.

$*$ She is very very beautiful in my eye.

She is very beautiful in my eyes.

*You are my everything for me.

You are everything for me.

Some over inclusion sentences above students used word "very" for twice and more than once, I should not be like that the use of "very just for one time. The next example is "my everything for me" it should be lost the word "my" because my and me were similar, differentiate both of them just in their position. Besides, the students committed errors caused by incomplete application of English rules. They add the items that should not be existent in well formed word.

The third is miss election, it occurs when the students cannot choose the appropriate word when constructing a well-formed sentence. For example:

*She wear balt, but variable

She wears belt, and it's various

*And she is $\underline{\text { shirt}}$, bad she hes point nose.

And she is short, bad she has pointed nose.

As we can see, there are many miss choice of errors in the students' writing. The above error sentences are evidence that the students lack of English lexical items. The words "variable" it should be "various", and the words "shirt" it should be "short".

\section{Lexical error in verb}

Verb is refers to a words likes actions or doing activity. Verb sometimes to be a main of sentences, and sometimes differentiate of verb are based on the tenses (past, present, future). There some parts of verb, they are: Infinitive (to-), for example: to take, to jump, to eat to run to read, ect. An action or activity: for example: take, went, jumping, talks, ran. Verb also can combine with noun, for example: they play hockey, Adam give Tia a gift. There are two parts of verb, they are: first, Lexical 
verb (we can say "dictionary verb") are verb which has meaning. For example: run, jump, eat, stand etc. Second, Auxiliary verb are helping verbs or auxiliary (to be) a verb that usually use for grammatical purposes. For example:

\section{They have all gone}

\section{They will not return}

They did not see the show

Have, will, did has not meaning because they are auxiliary, without them a sentences has meaning but has not grammatical meaning.

\section{a. Errors of verb in formal miss election.}

In formal miss election there are two types, the first is errors of verb in suffix, for example:

*The store is very very very good and attract.

The store is very good and attractive.

*She hobby are eat,pray,wathingtv, reading komik.

Her hobbies are eating, praying, watching tv, reading comic.

Example above show us that students lack of understanding the use of word, when it use as verb and when it use as noun. The word "attract" it should be "attractive" because it modifier characters of object. Next example is the word "eat" it should be "eating" because it describe about hobby it means the word "eat" above is noun.

The second is errors of verb in vowel based types, it a kind of error in spelling of written work. For example:

*She forever tich for kain.

She forever teaches for kindness.

*You can col me Nurul.

You can call me Nurul. 
Example above were errors appeared in vowel based types of verb. The word" tich" it should be "teach" and the word "col" it should be "call". Some of the errors in vowel-based type made because the students' lack of understanding of the English spelling. And also the students had not really mastered the English spelling, therefore they used inappropriate vowel in their sentences.

\section{b. Errors of verb in Misformation}

Misformation has three types. The first is borrowing, but in this type were not errors appeared. The second is coinage, and in this type there were not errors appeared too. And the third is calque were in this type were not error appeared.

\section{c. Errors of verb in Distortion}

The lexical error in distortion is caused by incomplete application of rules. There are four categories of distortion, the first is omission, characterized by giving rise to some an existent word. Errors of omission occur when the students omit the item that should exist in the correct lexis. For example:

* She wear a bracelet

She wears a bracelet

*Nurul us veil.

Nurul use veil.

The second is errors of verb in over inclusion it is the opposite of omission here the students add the inexistent item that should not be appeared in the correct word as the following examples showed:

- $*$ We also chaet together.

We also chat together.

- $*$ She is beatiful when smille.

She is beautiful when smile.

word "smille" it over inclusion of consonant $l$ it should be "smille", same with word "chaet" I should be "chat". the students committed errors 
caused by incomplete application of English rules. They add the items that should not be existent in well formed word.

The third is errors of verb in miss election, it is errors where students cannot choose the appropriate word when constructing a well-formed sentence. for example:

*I like cut Nisa is moment smille.

I like pinch Nisa is moment smile

$*$ She long hear.

She has long hair.

The words "cut" it should be "pinch" students mean in Indonesian language is mencubit so it incorrect if students choose cut, the right word is "pinch" the second example is "hear" students means hair but they lack of understanding so, they cannot differentiate between hair and hear.

\section{CONCLUSION}

As pointed earlier in chapter III, the data of this study are taken from English compositions written by the students of the eight grade students of Smp unismuh Makassar. The findings of this study show that there are many lexical errors found in the students' English sentences. It can be looked from the lexical errors that appear in their compositions. Although the students know well the words they are using, and difficult English spelling make them confused to write the lexical items.

Data from the present research points to the fact that the total number of lexical errors that the researcher found in the students' compositions is 198 errors, as appears in the chapter IV Based on these findings, the researcher can tell that the most prominent error from the data is formal miss election has 45 occurrences, misformation with 8 errors, while in, then followed by errors of distortion category with 145 errors.

Lexical errors in formal miss election category which are found from the students' writings are errors in applying suffix, vowel-based types; however, errors in prefix did not appear in the students' sentences. The total number errors 
of formal miss election found is 45 errors, and the major formal miss election that could be identified clearly here is suffix errors, there are 6 errors or 3, $03 \%$. Then, vowel-based type errors has 39 errors or 19, $69 \%$

On the contrary, misformation category has the least frequency occurrence in the students' compositions with 8 errors. Errors includes in borrowing 5 or 2 , $53 \%, 2$ errors or $1,01 \%$ in coinage, and 1 errors or $0,60 \%$ in calque.

The findings of this research indicate that distortion tend to be more frequent in the production of the students' English writings with 145 errors. The lexical errors in distortion category can be arranged as omission, over inclusion, miss election, and misordering. The most dominant errors that occurs is miss election with 71 errors or $35,86 \%$, and omission accounted for 53 errors or 26, $77 \%$, while over inclusion carried 21 errors or $10,61 \%$, and misordering did not appeared in the students writing.

Based on these findings, the researcher can tell that eight grade students of SMP Unismuh Makassar do commit lexical errors in their English writings. However, their biggest number of errors is distortion type, specifically in miss election category, in which they could not find the correct lexis in the process of constructing English sentences.

\section{REFERENCES}

Azkan, Nurul. 2013. Error Analysis on Students' English Descriptive Writing. Makassar: Unismuh

Brown, H. D. 1980. Principle of Language and Teaching. New Jersey: Prentice Hall, Inc

Carter, R. (1998). Vocabulary: Applied linguistics perspectives (2nd Ed.). London: Routledge.

Corder, S. P. (1992). A role for the mother tongue. In S. M. Gass \& L. Selinker (Eds.), Language transfer in language teaching (pp. 18-31). Amsterdam: John Benjamins.

Cruse. 1986. Lexical Semantics. Available online retrieved on 28 Juny 2013.www.lexical.com 
Channell, J. (1981) Applying semantic theory to vocabulary teaching, English language Teaching.

Corder, S. P 1973. Introduction Applied linguistic. England: Penguin Book Ltd.

Croft. 1980. Mistake and Error. Available online retrieved on 22 August 2013. WwW.erroranalysis.com

Darsono.2000. Teaching Vocabulary. Available online retrieved on 07 July 2013. $\underline{\text { www.teachingvocabulary.com }}$

Effendi \& Praja. 1993. Hubungan Belajar dan Menghafal. Available online retrieved on 29 Juny2013. www.hubunganbelajardanmenghafal.com

Eka L Koncara. 2005. Contain of Vocabulary. Available online retrieved on 13 July 2013. www.allaboutvocabulary.com

Ellis, Rod. 2003. Second language acquisition: An introductory course. Mahwa, NJ: LEA

James, C. 1998. Error in Language Learning and Use Exploring Error Analysis, London: Longman Group Ltd.

John M. Echols and Hasan Shadily. 2005. An English-Indonesia Dictionary. Gramedia: Jakarta.

Hamalik.2001. Criterion Referenced Evaluation. Available online retrieved on 15 June 2013. www.question of the cause lexical.com

Haryanto, Toni. 2007. Grammatical error analysis in students' recount text. Unpublished thesis. Semarang State University.

Jan- Arjen Mondaria. 1990. Journal of Efficiently Memorizing Words with the Help of Words and "Hand Computer" Theory and Applications. University of Gronigen.

Jian T. H. (1981). Error Analysis: A study of errors made in written English by Chinese learners. Master Thesis of English Department, National Taiwan Normal University.

Judith E. Brisbois, 1995. Connection between First and Second Language Reading. United State Air Force Academy.

Laufer, B. (1991). Some properties of the foreign language learner's lexicon as 
Evidenced by lexical confusions. International Review of Applied Linguistics.

LaurinaDimpudus. 2011. Aspect of Vocabulary English Vocabulary. Available online retrieved on 10 June 2013. www.aspectofvocabulary.com

Mazur Steward Marrinne. 1988. Journal of the Effect of Vocabulary Overview Guide on Vocabulary Comprehension and Retention. University of Toledo.

Masiosinaga.2011. Lexical in Vocabulary. Available online retrieved on 28 June 2013. http://www.masinosinaga.com/id/

Meriam- Webster. 2003. Collegiate Dictionary. Available online retrieved on 20 August 2013.www.citycollegiate.com

Norrish, J. 1983. Language Learners and Their Error. London: Macmillan Press.

RahmatSolihin 2013 “Improving students' ability in writing descriptive text by using reciprocal approach of SMA Madani Makassar"

Rahayu. 2002. Variety of Media and Method. Available online retrieved on 07 July 2013. www.methodinteaching.com

Richard J. C. 1974. “A Non- Contrastive Approach to Error Analysis". In Richards, J. (Ed.). Error Analysis. Perspective of second language acquisition error. Longman

Sanal. 2008. Error Analysis of Language. Retrieved online on 22 august 2013. $\underline{\text { www.analysiserroroflinguistic.com }}$

Saragi. 1978. Definition of Vocabulary. Available online retrieved on 29 June 2013. www.definitionofvocabulary.com

S. Nateshan. 2000. Lexicalization in English. Available online retrieved on 30 June 2013. www.lexicalization.com

SwaraBhaskara. 2011. Different of Vocabulary learning English. Available online retrieved on 12 July 2013. www.vocabularylearning.com

Supralan. 2009. Problem in Memorizing Vocabulary. Available online retrieved on 28 Juny 2013.www.memorizingmethod.com

SyarifElnina. 2009. "Improving students writing through mind mapping technique of the second grade of SMA 1 Tamalatea" 
Thornbury. 2003. Part of Speech. Available online retrieved on 08 June 2013. www.partofspeech.com

Torrey, Jane w. 1971. Second Language Learning. New York: Person Education 